\title{
Managing Difference: gender and culture in humanitarian emergencies
}

JENNIFER HYNDMAN, Arizona State University West, USA

ABSTRAGT The United Nations High Commissioner for Refugees (UNHCR) has a mandate to respond to crises of human displacement on a global scale. The ways in which the organization conceives of gender and culture in this humanitarian context are problematic because they tend either to essentialize 'woman' and 'culture' in the planning process or to minimize the meaning and implications of these differences vis-à-vis gender policies which focus on integration. In this article, the discourse of ' $U N$ humanism' is analyzed, noting a long-standing tension between culture as shared humanity and culture as a pivotal basis of difference. Drawing on current research relating to UNHCR's gender policies and on initiatives against violence towards refugee women in camps, the implications of overarching frameworks which attend to gender and cultural differences are discussed. Strategies to avoid authenticating or fixing categories of difference, on the one hand, and to avoid treating gender and culture as simply variables, on the other, are proposed in the context of emerging transnational feminist practices. Transnational approaches point to important interventions which may serve to unravel the dominant discourses of UN humanism and vulnerable groups that continue to organize UN refugee and humanitarian operations today.

Responding to humanitarian emergencies is fraught with difficulties from the outset. Human displacement created by conflict, ethnic cleansing, or politically-induced famine often emerges unannounced, rendering it difficult to plan for in the first instance. No world region is immune to humanitarian crises or to the implications of forced migration. In 1997, more than 22 million people were affected by displacement, both within and beyond the borders of their home countries (United Nations High Commissioner for Refugees [UNHCR], 1997). Humanitarian responses invariably involve communication across several languages, interpretation across more than one cultural divide, and the negotiation of political agreements at every step. Increasingly, assistance is being provided in war zones where the conditions of work are far from ideal. Yet something has to be done. The shortcomings of humanitarian aid and its delivery in particular situations are generally outweighed by a political consensus that action must be taken.

This article sets out to 'navigate the pitfalls of universalizing talk which mute critical aspects of diversity and difference' among people of different genders and cultural locations, without authenticating a particular approach or set of categories which fix identities in the context of humanitarian crises (Crosby et al., 1996, p. 3). The ways in which difference is used, managed, and theorized both fuel conflict and potentially open up other, less violent and less hierarchical spaces. Notions of belonging based on 
constructions of common ethnicity or nation exacerbate differences between 'us' and 'them', often in strategic ways. During the Quebec referendum on separation in 1996, a minority of ethnic nationalists called for a French (i.e. non-immigrant) Quebec based on the exclusionary concept of pure laine (Quebeçois with ethnic French heritage). The racist connotations of this position were not well tolerated by federalists, nor by the majority of separatists. Nonetheless, it was used as a strategy to fuel the separatist cause vis-à-vis ethnic nationalism. Elsewhere such language has been used to exacerbate differences and mobilize people to engage in hateful, violent acts, including ethnic cleansing and rape. At the same time, however, containing difference within a dominant discourse of unity - despite the historically and geographically contingent experiences and identities of particular groups - is equally problematic. Human rights instruments, which espouse the legal entitlements of universal subjects, and international laws pertaining to refugees, for example, may on paper apply equally to all countries that are signatories, but the outcome of such measures is uneven because individual nations and groups of people within them are unequally positioned in relation to one another. Differences defined through hierarchical relations of power and unequal subjects within webs of humanitarian action have the potential for both conflict and affinity. How, then, in the context of humanitarian assistance can one practically avoid the consequences of constructing subjects as universal-a move which effectively subsumes differences of gender, ethnicity, and nationality-without essentializing identities and reifying these same categories?

Research focusing on the organizational culture and politics of the UNHCR provides the basis for this article. The UNHCR orchestrates responses to what are most often called 'humanitarian emergencies', crises of human displacement within and across political borders. Its mandate is to provide protection and assistance to involuntary migrants, and to seek permanent solutions to their displacement. During 1994-95, I conducted ethnographic fieldwork at three separate sites of UNHCR operations. The organization has its headquarters in Geneva, a location from which directives are disseminated and to which information and field reports flow. Based on experience working with a non-governmental organization (NGO) in Kenya and UNHGR in Somalia, sites in Geneva, Nairobi, and in the Dedaab camps near the Kenya-Somalia border were selected for the study of this geographically-distributed UN agency. The sites represent three distinct levels of authority within a highly hierarchical organization. Both anthropologists and geographers have made the call to 'study up', to analyze and theorize institutions, organizations, and other power brokers that govern human relations rather than to study the governed themselves (Abu-Lughod, 1991; Pred \& Watts, 1992). I have adapted this methodological approach with a view to repositioning the academic gaze, a move which may well present its own problems of access, duplicity, and privilege. Nonetheless, it also presents different opportunities for analyzing pervasive issues of gender and cultural politics, racism, and the governance of safe spaces for displaced people. I speak of duplicity because of my positioning both inside and outside the humanitarian project, both as a participant and a critic. In 1992 and 1993, I worked as a consultant for CARE International, an NGO operating in Walda refugee camp, and as a field officer for UNHCR as part of its Cross-border Operation in Bardera, Somalia. My subsequent analysis of these experiences provoked much of the research on which this article is based.

Many of the ideas for this article also stem from discussions held at the first meeting of the Women in Conflict Zones Network in November 1996. The Network is a collection of feminist scholars, community organizers, UN agencies, and human rights 
organizations. A number of feminist scholars participating in the Network collaborate with groups of women organizing against conflict in ways that cultivate affinity and advance work towards resolution where conflict prevails. As feminists, we aim to take responsibility for the implications of our research and put the welfare of the researched group and its members before that of the research objectives. Others are activists and scholars whose work is as political 'on the ground' as it is 'in theory'. Still others are working in war zones and refugee camps as feminist researchers to analyze the gendered outcomes of conflict and the strategies employed to govern these spaces: how disorder is ordered. No one approach is sufficient to meet the challenges posed by mass displacement, ethnic-based violence, and conflict. At the same time, linking these various projects and people without subscribing to categories of increasingly institutionalized difference is a vital part of feminist politics. Towards the end of this article, the meanings and political implications of these connections are advanced.

In this article, I am concerned principally with the human impact of conflict and responses to it. In particular, I focus on the processes of managing displacement and asylum by the UN; the ways in which these are gendered; and the cultural politics they entail in the context of refugee camps. How can institutions with global mandates conceptualize issues that differ across cultural and other contexts? And how can they act without systematically privileging certain gender identities over others? Modes of 'managing diversity' and UN approaches to difference are discussed first, as a framework for subsequent analyses. A short discussion of UNHCR gender policies follows, underscoring the liberal tendency to subject gender difference to 'mainstreaming and integration'. This creates a context for discussion of a particular, and somewhat puzzling, UN initiative called the Women Victims of Violence (WVV) project, an initiative launched in the Kenyan camps for Somali refugees. The project highlights the dangers of subscribing to or unintentionally reproducing categories of difference, without attending to their practical implications. Finally, these approaches are analyzed in terms of their theoretical and on-the-ground implications.

\section{The Perils of Perfect Pluralism}

The research that provides the basis of this analysis does not focus exclusively on the conditions of Somali women in the camps and the antecedent civil war in Somalia which had displaced them, but rather on the organization that has managed this crisis of forced migration. UNHCR does important work, and the scale of its operations has increased dramatically in the 1990s (UNHGR, 1995). The ways in which it 'manages' difference among groups of displaced people thus warrants careful examination and consideration. The agency's outlook, history, and geography still espouse a universal humanism-albeit a subtle one that recognizes certain bases of difference. Its treatment of gender and cultural differences provides a case in point. UNHCR maintains that its mandate is a preventive one: 'to manage ethnic diversity in a way that promotes tolerance within and beyond national borders'(UNHCR, 1993a, p. 22). Despite the ground-breaking work of feminists and other scholars in development circles to deconstruct dominant discourses and recover the voiceless subjects of these discourses (Marchand \& Parpart, 1995; Escobar, 1995), the still universal humanist subjects of a multicultural United Nations remain intact.

The UN 'family of man', 'family of nations', and 'international community' are unavoidable concepts for feminists concerned with deconstructing the universal subject and its attendant constellations of social power. Each term is an expression of the 
overarching narratives of statehood and humanism. Liisa Malkki (1992) explains how ritualized evocations of common humanity are constructed and celebrated as an egalitarian diversity among peoples and nations. In particular, she identifies the 'family of nations' and the 'international community' as discursive practices which serve 'to reproduce, naturalize, legitimate and even generate "the nation form" all over the world" (Malkki, 1992, p. 42). Her main point is that terms like 'international community' obfuscate the unequal power relations among states, especially the hegemony of European nations. Differences among countries are constructed as plural and are valued as a part of a diverse whole. In Malkki's analysis, difference is domesticated and contained within a liberal-humanist discourse of 'cultural diversity'. Two processes often occur together: 'a creation of cultural diversity and a containment of cultural difference' (Bhabha cited in Malkki, 1992, p. 60). Globally there are at least 5000 ethnic groups organized within roughly 200 independent states. Just as cultural and political differences among states are balanced within a contained order, so too are differences within large organizations such as the UN. Akin to criticisms of multiculturalism, Malkki's argument challenges the idea of cultural containment within a hegemonic, overarching framework of power in which 'the North' dominates 'the South'.

The tension between culture as a basis for universal human experience and culture as the primary basis of difference has important social and political implications for humanitarian practices. As an organizational culture, UNHCR is an expression of this tension today, embodying an antagonism between the acceptance of plural cultures and the standards of international law and universal human rights. In one of UNHCR's most recent public relations posters, issued ostensibly to promote tolerance of refugees, dozens of different toy LEGO people are pictured-conveniently all in yellow; the text states:

You see, refugees are just like you and me. Except for one thing. Everything they once had has been left behind ... we are asking that you keep an open mind. And a smile of welcome.

This plea for acceptance and understanding of difference on the basis of a shared humanity speaks to and is constructed as part of a European cultural dominant. While its intentions are laudable, its politics are predicated on minimizing differences to engender tolerance and even acceptance. UNHCR nuances this effort to promote sameness with the T-shirts it sells which read, 'Einstein was a refugee'. bell hooks makes a parallel argument:

Their [white people's] amazement that black people watch white people with a critical 'ethnographic' gaze, is itself an expression of racism. Often their rage erupts because they believe that all ways of looking that highlight difference subvert the liberal conviction that it is the assertion of universal subjectivity (we are all just people) that will make racism disappear. They have a deep emotional investment in the myth of 'sameness' (hooks, 1992, p. 339).

Rather than framing difference as 'almost-the-sameness' or as the object of a benevolent act of accommodation, difference can be a basis for connection. Connecting across difference, however, does not lend itself easily to posters or T-shirts.

Transnational practices require analyzing dominant constructions of difference and acting to change them in relationally grounded ways. In Belfast, coordinators from Irish women's centres on both sides of the Protestant/Unionist-Catholic/nationalist battle have organized the Women's Support Network (Cockburn, 1996). The Network is consciously cross-communal, although it exists more as a vehicle for social change than 
as a symbolic gesture. Women from its member groups work to address the poverty and violence in working-class areas of the city in which the centres are based. Linking these women, the Network works for political visibility and conveys knowledge and experience among its members. The women of the Network defy the difference that underpins much of the ethnic violence in Belfast, and in so doing, create an unusual coalition. During conflict in the former Yugoslavia, Women in Black, representing various ethnic backgrounds, silently protested the mobilization of ethnic nationalism to legitimate war in Belgrade, at once mourning for those lost to the conflict and creating cause for reflection and potential change among those who took notice. Drawing their own transnational links, a group of feminists in Toronto recently formed a Women in Black group - albeit to address loss of entirely different scope-to protest and mourn the demise of the welfare state and its most basic provisions in Ontario, Canada.

In North America, transnational feminist and labor lobbies concerned with the impact of the North American Free Trade Agreement (NAFTA) make connections across borders, languages, and industrial sectors based on shared political goals (Sparke, forthcoming 1999). Transnational economic connections have been forged where shared interests are identified. In a more political context, the diffusion of national diasporas in various geographical directions generates the possibility of connecting cultural groups dispersed across space, and of forging connections across cultural and geographical locations where people have similar political objectives. People displaced from Burma, also known as Myanmar, offer a case in point. Student and minority groups, as well as a government-in-exile have generated an impressive geography of resistance-from the Thai-Burma border to Washington DC - to protest at the repressive rule of the State Law and Order Restoration Council (SLORG) that governs Burma. The history of conflict among the various ethnic groups represented by these activists, cultivated in part by the colonialism in Burma, created deep divisions, but ultimately a coalition 'front' against SLORC has proven a more viable political tactic.

The question remains, however, as to how UNHCR - an apolitical organization whose mandate is to deliver humanitarian assistance, and not to engage in the politics of the conflicts which precipitate displacement-might approach difference on a global scale. It begs a more transnational approach to broaching difference. If one approaches relationships among cultural groups and the spaces they occupy not as harmonized 'us' and 'thems' living together, but as a series of unequal and uneven links between different subjects, then the question itself changes. Difference is not a question of accommodation but of connection.

\section{Culture: shared humanity or the basis of difference?}

This section begins by examining some of the ways in which the categories of 'race' and 'woman' have been constructed in subordination within a discourse of 'UN humanism'. Historically, racial equality preceded concerns for gender equality within the UN framework. The universal subject, the UN 'family of nations', and international human rights were part of this discourse of humanism that emerged from the aftermath of the Second World War. Despite the political, intellectual, and cultural change since that time, they remain the basis of much international law and UN institutional practice almost 50 years later. In order to create international declarations, instruments, and laws protecting human rights, a common bearer of these rights - the universal subject-was born. The universal has always been qualified by the particular, distinguished by culture, national integrity, and most recently concern for gender equity. UNHCR has been 
forced to face the issues of gender and cultural politics head-on. The pervasive and, in some ways, persuasive discourse of human rights and universal standards of humanitarian assistance in the face of displacement remain, however, deeply embedded in the structures, policy, and practice of the organization today.

I recognize that many feminists and other scholars eschew the 'vulgar' strand of humanism broached here for 'it is now widely accepted that the autonomous, neutered and sovereign subject at its core was a fiction, implicated in an ideology of humanism which suppressed the multiple ways in which subjects were constructed in order to promote a white, masculine, bourgeois subject as the norm, from which others were to be seen as departures or deviants' (Gregory, 1994, p. 265). Furthermore, development theorists have exposed an economy of discourse and unequal power relations encoded in the charitable gestures of aid and assistance (Escobar, 1995). 'UN humanism' might be considered an ideological construct or discourse which is past its prime. Nonetheless, remnants of it are alive and well in locations of conflict and displacement.

\section{'The Birth of the UN Family'}

Culture never stands alone but always participates in a conflictual economy acting out the tension between sameness and difference, comparison and differentiation, unity and diversity, cohesion and dispersion, containment and subversion. (Young, 1995, p. 53)

The legal and organizational protocols of the UNHCR are an expression of the larger liberal discourse of UN humanism. This brief account of the 'birth' of UN humanism elucidates constructions of 'race' and gender within UN discourse more generally, followed later by UNHCR gender policies in particular. Robert Young (1995, p. 54) chronicles debates over 'race' in the nineteenth century and suggests that 'culture' has replaced 'race' in twentieth-century debates, but remains otherwise much the same: 'Culture has always marked cultural difference by producing the other; it has always been comparative, and racism has always been an integral part of it ... Race has always been culturally constructed. Culture has always been racially constructed'. Young usefully documents arguments about racial difference and superiority in the nineteenth century, despite the tautology of his argumentation about the mutual construction of race and culture. Monogenists believed that all human beings belonged to one 'race' because they were the creation of a divine god, while polygenists - the progenitors of 'miscegenation'- - maintained that there were distinct 'races' hierarchically positioned in relation to one another [1]. Throughout the nineteenth century, 'whites'-the interlocutors in these debates-were 'naturally' considered the superior race by the polygenists. This period gave rise to tests, such as the measurement of the human cranium as an indicator of intelligence. '[F] or two hundred years culture has carried within it an antagonism between culture as a universal and as cultural difference, forming a resistance to Western culture within Western culture itself' (Young, 1995, p. 54). UNHCR embodies this antagonism and embraces both humanism's universal subject and the concept of cultural difference as a means of accommodating difference. While 'culture' may have supplanted 'race' in measuring difference, the politics and distance it generates remain the same.

In 1948 the Universal Declaration of Human Rights was proclaimed, a declaration in which 'universal man' replaced 'international man' in a final amendment. René Cassin, who lobbied for this change, argued that "universal" man is more easily extracted from the complications of history' (Haraway, 1989, p. 198). He did not consider the 
ramifications of these 'complications', namely the importance of cultural and political geographies among nation-states and implications of gender for 'universal man'. Before long, the abstract, 'race'-neutral, gender-blind concept of humanity encountered its own limitations. In 1950 and 1951, the United Nations Educational, Scientific, and Cultural Organization (UNESCO) published statements on the (scientific) nature of 'race' and racial differences. Donna Haraway spells out the connections between these statements and the construction of 'universal man' after the Second World War:

the authority of the architects of the modern evolutionary syntheses was crucial to the birth of post-W.W.II universal man, biologically certified for equality and rights to full citizenship. Before W.W.II, versions of Darwinism, as well as other doctrines in evolutionary biology, had been deeply implicated in producing racist science as normal, authoritative practice. It was therefore not sufficient for social science, set across an ideological and disciplinary border from nature and natural science, to produce anti- or non-racist doctrines of human equality and environmental causation. The body itself had to be reinscribed, reauthorized, by the chief discipline historically empowered to produce the potent marks of race-Darwinian evolutionary biology. For this task, 'behavior' would be the mediating instrument. (Haraway, 1989, p. 199)

Authorized by science, the 'birth' of a universal subject was timely. Poised between the victory over fascism and the horror of the Holocaust, the politically significant emergence of the 'united family of man' was legitimized by evolutionary biology and physical anthropology. The rallying point for humanists was that the scientific differences among individuals of the same so-called 'race' were greater than those among different 'races', the political corollary of which was the 'birth of UN humanism' and its attendant declarations, legislation, and human rights instruments which shape the humanitarian terrain today.

This UN discourse was implicitly and explicitly gendered. Concerned mainly with erasing racial difference, gender was a secondary consideration at best. The statements of the 1950s spoke of 'universal brotherhood', a language of androcentrism, if not exclusion. The gender-blindness of UN humanism generated the 'Man-the-Hunter' image produced and institutionalized by scientific meetings such as the 1955 Pan-African Congress in physical anthropology held in Nairobi. Discussion of racial politics and of natural tendencies to cooperate was itself gendered: 'Man the Hunter's and UNESGO man's unmarked gender were part of the solution to one kind of racism at the inherited cost of unexaminable, unintentional, and therefore particularly powerful, scientific sexism' (Haraway, 1989, p. 201). In addition to the displaced notion of difference ushered in by the UNESGO Statement on Race, the cost of this solution was a kind of scientific sexism within 'the UN Family'.

The gendered dimension of these 'race' politics was perhaps less obvious to UN humanists than the exclusion of 'Woman' from the ranks of universal brotherhood. Although the UN established the Commission on the Status of Women (CSW) as early as 1947, a world women's conference proposed in 1946 did not materialize until the declaration of International Women's Year in 1975 (Galey, 1995; Allan et al., 1995). A culmination of women's activism and issues inspired the UN Decade for Women between 1975 and 1985 (Winslow, 1995; Pietilä \& Vickers, 1996). The decade was punctuated by the 1985 UN Conference on Women in, somewhat ironically, Nairobi, the site of the 1955 scientific meetings which ratified only the Man-the-Hunter image. 'The UN had to respond to the manifestations of the revolution in gender that is 
occurring all over the planet in very homogeneous, contradictory, and internally contentious ways' (Haraway, 1989, p. 286). The 1995 World Conference on Women in Beijing and the NGO Forum held in Hairou, China marked another decade of UN efforts to incorporate a gender analysis. For the first time, the UN conference's Platform of Action outlined the strategic importance of protection, assistance, and training for refugee women and those internally displaced (Pietilä \& Vickers, 1996). This represents a victory for UNHCR, whose aim has largely been to integrate gender and the situation of refugee women into mainstream agendas. All of these UN conferences challenged assumptions of a 'universal brotherhood', and created a platform for further action at the end of each conference. Even so, the legacy of 'universal man' remains evident in the ways in which UN agencies deal with difference today.

\section{Gender Policy at UNHGR}

While vast improvements have occurred, the implementation of UNHGR policies and projects aimed at promoting women in the 1990s remains problematic. If one takes culture as both universal and a basis of difference, then the development of policies and practices applicable, in theory, to a vast number of geographical regions and cultural groups is made particularly difficult. In this section a cursory overview and analysis of UNHGR's gender policy on paper is followed, in the next section, by a case study of one UNHCR project aimed at promoting women in practice. A close reading of this project illustrates some of the contradictions between and complications of policy and practice. The Women Victims of Violence Project, an initiative to protect refugees from sexual violence, raises questions of gender policy versus gendered practice in UNHCRsponsored refugee camps.

The advent of gender equity policies at UNHCR occurred in the late 1980s. On paper, UNHCR's gender-based initiatives are an impressive collation of feminist analyses and recommended action [2]. They include liberal and other feminist sensibilities which address issues of discrimination, violence, and systemic material inequality affecting women (UNHCR, 1993b, 1993c). On one hand, the frequent use of the category 'woman' by UNHGR as a primary organizing concept essentializes and reinforces the primacy of female difference over ethnic, clan, and other axes of identification (UN, 1993) [3]. On the other, this usage seems contrary to the basic liberal feminist principle articulated in UNHCR policy, namely 'mainstreaming and integration'. While certain groups of women refugees are listed as 'vulnerable' and requiring special assistance in the camps, other planning documents insist that women be equal partners in decisionmaking processes and that they should have equitable access to services and resources (UNHCR, 1991, 1994a; Anderson et al., 1992).

These two approaches to women and gender are not necessarily mutually exclusive. For example, the same Somali refugee woman may find herself separated from her family as she flees conflict at home, and later, upon arrival in a refugee camp emerge as a leader and decision-maker, say as a health professional. In the first scenario, she is justifiably 'vulnerable' because her family - an accepted cultural form of protection-is absent. Conflict and displacement have historically often destabilized social relations, and it is possible that this person could well be at risk. In the second scenario, however, the skills and experience she brings to the camp make it equally possible that she becomes part of the decision-making apparatus in the health sector. While they appear contradictory, concepts of women as equal partners and as part of a vulnerable population can coexist. The appropriateness of either approach must, however, be analyzed in the 
contingent historical and geographical context of a particular humanitarian situation. 'Women refugees' are not vulnerable in any essential way, nor are they all equal participants in the daily governance of a refugee camp. Their locations are at once designated by UNHCR's policies and contingent upon the history and place in which they find themselves.

UNHCR's approach to women refugees cannot be viewed as coherent, unitary, or internally consistent. Nor should it. The main purpose of UNHCR policies to promote women is to encourage and create change within the organization, so that operations on the ground are also positively affected. The barriers to such organizational change, however, are significant. One NGO representative based in Geneva noted some of these organizational obstacles to developing gender policy expressive of a feminist politics at UNHCR:

[those promoting gender equity at UNHCR don't] want to use feminism or these terms ... the culture just refuses to deal with anything of the sort.

... and even though [UNHCR's] calling it 'people-oriented', [it's] getting the backlash ... it's not easy. It's easy to critique a person's efforts, but once you're in it's not easy. Like here, I haven't yet said openly that I'm a feminist-I have with the women and certain groups, but there is an image of feminism, people don't recognize that there are feminisms. ... (personal interview, senior NGO staff person, 28 October 1994)

Taking gender equity and the provision of refugee assistance grounded in a sustained analysis of gender to mean 'feminist' at UNHCR, sustained efforts to integrate feminist policies are, in fact, struggles that demand support from inside and outside the organization [4].

Promoted by the office of the UNHCR Senior Coordinator for Women Refugees, the 'People-Oriented Planning Process', or POP as it is called, is a euphemistic title referring to training in gender analysis and culturally-sensitive community planning (UNHCR, 1991; Anderson et al., 1992). Both POP and the 'Guidelines on the Protection of Refugee Women' identify the physical spaces in which refugee women live as important to ensure safety and equitable access to basic services and supplies. UNHCR recognizes that women refugees are often more susceptible in camp situations because family protection and traditional authority structures break down and economic support is less available (UNHCR, 1993a). Camp layout and location are also acknowledged as important considerations in planning refugee camps.

Historical context, regional geopolitics, cultural and gender differences, however, are left for fieldworkers to 'fill in' once placed in the refugee camps. In development circles, feminists have long challenged many of the assumptions aid organizations make with respect to gender and the roles of women in development. Several feminist scholars have noted that the approaches of 'women' and 'gender' in development are predicated upon assumptions which subsume, segregate, and essentialize the locations of women (Marchand \& Parpart, 1995). From Women in Development (WID) to Women and Development (WAD) to Gender and Development (GAD) approaches, development discourses fix gender in particular ways (Parpart, 1995). Arturo Escobar (1995) has referred to development discourse as the 'bureaucratization of knowledge about the Third World', an important concept to which I will return. Some development approaches treat women as subjects excluded from the development process. Women are considered partners in decision-making who should be integrated fully into existing political, economic, and social structures. Others cast women as poor and vulnerable 
mothers with 'special' needs that must be recognized and tended to by aid organizations; they are explicitly included, but their agency is limited. Some projects are conceived by women for women and bypass the dominant circuits of power and authority that the other two approaches rely upon. All represent what Mitu Hirshman (1995, p. 44) calls 'the be-all and the end-all of the humanist project: the improvement of the human condition'. Like Hirshman, I do not simply dismiss these approaches because of their humanist assumptions, but aim to expose some of the limitations these assumptions pose.

'People-oriented planning' fixes gender relations and cultural identities by the very schemata and structuring procedures embedded in UNHCR's routine work practices. This institutional production of social reality works because it is represented and thus preserved through a series of textual and documentary forms: 'texts are invariably detached from the local historical context of the reality that they supposedly represent' (Escobar, 1995, p. 108). Following feminist sociologist, Dorothy Smith (1983), facts are an aspect of social organization, a practice of knowing that employs categories familiar to the knower, but not necessarily to the one 'known.' It is a practice that constructs an object or person as external to the one inside the organization.

For bureaucracy is par excellence that mode of governing that separates the performance of ruling from particular individuals, and makes organizations independent of particular persons and local settings ... Today, large-scale organization inscribes its processes into documentary modes as a continuous feature of its functioning ... This [produces] a form of social consciousness that is the property of organizations rather than of the meeting of individuals in local historical settings. (Smith cited in Escobar, 1995, p. 109)

In such situations, it follows, the culture of the institution--in this case UNHCRproduces a profile of the external culture from its own perspective. 'The various agencies of social control', writes Smith (1993, p. 12), 'have institutionalized procedures for assembling, processing, and testing information about the behavior of individuals so that it can be matched against the paradigms'. The UNHCR guidelines and POP approaches are, then, part of an institutional bureaucracy, which attempt to create a grid of intelligibility for the agency without necessarily linking the complications of local histories, cultures, and conflicts to their considerations (Sassen, 1996). POP may well have potential to change some practices within UNHCR's organizational culture, but it is unlikely to capture the cultural and political complexity of social relations in a context of specific humanitarian emergencies.

The POP framework advocates a three-step approach to camp planning: preparation of a refugee population profile to analyze context; analysis of previous and existing patterns of activities among refugees, such as the gender divisions of social and economic responsibilities; and a comparative analysis of what resources refugees controlled and used before they arrived and what they control and use in the current context. These analyses, grounded in local conditions and cultures, are to be applied to the organization of food distribution, physical layout of camps, and medical assistance for refugees. The POP framework has much in common with 'gender and development' approaches to planning; however, at UNHCR, it is a tool which emphasizes gender sensitivity without naming it, and one which is unaware of the role it has in constituting gender as a knowable set of relationships in humanitarian situations.

An alternative to POP might mitigate the ethnocentrism of this particular humanitarian approach by connecting the social, political, economic, and cultural locations of people who have been displaced, through 'the meeting of individuals in local historical 
settings' (cf. Smith, 1993). UNHCR has taken partial steps in this direction by, for example, offering POP training to African women who are community workers and encouraging them to 'interpret' the planning framework within an appropriate cultural context. While this is a positive development, it nonetheless attests to the adaptation of an approach, without rethinking the epistemological issues of whose knowledge and/or planning approaches prevail and their practical implications. An alternative approach might also recognize that humanitarian assistance does not have the same meaning in all places, does not include all groups, and may not have equivalent outcomes, despite similar policy and application. The POP initiative does attempt to include the specific dynamics of people and place, but it needs to go much further. Cultural politics, prejudice, and the historical layers of conflict and coalition in a given place cannot simply be added to such a framework. Cultural workers within the humanitarian bureaucracy and interlocutors 'on the outside' are sorely needed to create bases for communication and exchange, even if this occurs between participants with unequal access to power.

Traceable to UN humanism, UNHCR policies pertaining to refugee women and to refugees of other cultures fail to recognize the ways in which 'women' and 'culture' are constructed in subordination. In an examination of gendered culture, Tani Barlow (1994) notes that the term 'woman' was not part of terminology in China until after Western influence and that it came into use partly as an instrument of control on the part of the state. Inderpal Grewal has argued that international institutions like the World Bank and the International Monetary Fund (IMF) contribute to the interpellation of female subjects in varied ways in many parts of the world:

while the term 'woman,' as a political category, cannot be dismissed so easily, what needs to be remembered is not only Simone de Beauvoir's notion that 'woman' is a social construct, but that first, women are constructed differently within different social categories such as class, caste, and so on ... even while it is important to critique an ahistorical category of 'woman,' it is just as problematic to seek authentic versions of women's locations within societies. (Grewal, 1994, pp. 243-244)

Faced with crises of displacement which require practical responses to assist refugees regardless of gender or culture, UNHGR is also confronted with the need for transnational practices which do not fix gender identities. A multicultural framework incorporates differences of gender and culture as plural expressions of diversity, without necessarily examining power relations among distinct groups (see Shohat \& Stam, 1994). Multiculturalism includes differences but does not allow them to alter the master plan or narrative of which it is a part. The deconstruction of dominant narratives of power and the reconstruction of other subject locations comprise a strategy by which UNHCR can resist inserting 'woman' and 'culture' within a Western economy of difference. Transnational practices can break down authoritative power relations by making connections across cultural and gender differences, rather than within planning frameworks based on Western notions of community development. Engagement, translation, communication, and action determined by parties on all sides of the humanitarian situation constitute some of these practices.

Transnational practices would involve ongoing meetings with refugees and their involvement at all levels of humanitarian response, not simply consultations with them regarding pre-given models of refugee planning and management.

The concept of intervention then needs deconstructing so that it is seen for what it is-an ongoing, socially constructed and negotiated process, not simply the 
execution of an already-specified plan of action with expected outcomes. One should also not assume a top-down process, since initiatives may come from 'below' as much as from 'above' ... Using the notion of intervention practices allows one to focus on the emergent forms of interaction, procedures, practical strategies, and types of discourse and cultural categories present in specific contexts. (Long, 1995, p. 35)

Refugees and other displaced persons have to become part of the implicit 'we' in the 'us'-'them' equation in order to take apart the paternalist narratives, frameworks, and planning policies which organize their difference. This is not to say that they are the same as non-refugee humanitarian workers, nor do they necessarily have comparable resources and social power. They are, however, likely to be among the best local and historical interpreters and strategists of crisis situations. As it stands, refugees remain the objectsrather than the subjects - of humanitarian planning, despite long-standing agreement on this point. While the challenges of implementing gender-based policy within UNHCR's organizational culture are significant, the challenges of humanitarian practice in conditions of displacement are at least as difficult, if not more so.

\section{Women Victims of Violence (WVV): combating sexual violence}

Sexual coercion, torture, and rape are relatively common occurrences in conflict zones. Despite being recognized places of asylum for people fleeing persecution, refugee camps can also be unstable environments where residents are susceptible to sexual and physical violence. In the North-east Province of Kenya, where a history of systematic economic marginalization includes banditry, widespread insecurity has only been exacerbated by the arrival and temporary settlement of tens of thousands of refugees. Those who leave the camps for hours at a time in search of firewood with which to cook - predominantly women and girls - are vulnerable to bandit attacks. After nightfall, unarmed households-especially those known to be headed by women-have been the easy targets of bandits from within the camp itself. During my stay, several attacks of rape, defilement, and 'spouse assault' were reported and documented.

From its inception, the WVV Project was an immensely 'fundable' contradiction in UNHCR policy. In October 1992, the US-based human rights monitoring group, Africa Watch, documented sexual violence against Somali refugee women in the Dadaab camps. This report fueled international concern about rape against refugee women in the area. In the same month, UNHCR hired a consultant to investigate the allegations further. Seven months in the making, her report documented 192 specific cases of rape among Somali woman, noting that these were 'only the tip of the iceberg' (UNHCR, 1993d). She proposed a comprehensive response to this sexual violence which became the 'Refugee Women Victims of Violence' special project. The project outlined four specific objectives, including (1) the provision of counseling, therapy, and medical services for those affected by sexual violence; (2) improved physical security in and around the refugee camps to prevent future violence; (3) material assistance and skills training to enhance the livelihood of 'victims'; and (4) increased awareness of the problem among law enforcement personnel, as well as staff and the general public.

Based on these objectives, WVV was a special project. It focused initially on 'women' refugees rather than all refugees affected by physical assault and sexual violence in and near the camps, and it aimed to assist those affected by rape but not by other types of trauma. By focusing on vulnerable women, a senior manager in Geneva admitted 
that WVV contravened UNHCR's own integrationist policy on refugee women (UNHGR, 1990; personal interview, UNHGR senior staff member, 25 October 1994). The project fell prey to some of the same critiques made of development literature relating to women:

Much of the WID [Women in Development] and Gender and Development (GAD) literature represents Third World women as benighted, overburdened beasts, helplessly entangled in the tentacles of regressive Third World patriarchy. (Parpart, 1995, p. 254)

In the case of WVV, the Western funders of the project could 'save', or at least assist, vulnerable Somali women from the chaos and calamity of the camps.

The WVV project provided specified services and potential material assistance to those refugees who could demonstrate that they were raped, creating a dilemma for many women. The problematic denotation of women as 'victims' in the project's title was a minor issue next to the inscription of shame and of violence on the bodies of the Somali women who were 'found out' and often disowned by their family. I borrow here from Teresa de Lauretis's (1990) notion of the body as the site of material inscription of power. In the case of rape, a woman's body can be thought of as the site of a double inscription: of sexual violence, and of institutionalized therapies to treat the affected body. Naming practices matter, and the project's designation 'victims of violence' introduced yet another layer of problematic power relations to the incident of rape.

Through travelling to other people's 'worlds' we discover that there are 'worlds' in which those who are the victims of arrogant perception are really subjects ... even though in the mainstream construction they are animated only by the arrogant perceiver and are pliable, foldable, file-awayable, classifiable. (Lugones cited in Kaplan, 1994, p. 150)

The WVV Project posed a number of related problems from the start [5]. On the one hand, if a refugee woman sought assistance through a WVV counselor, she could easily become stigmatized as a rape victim and ostracized by her family and/or community. On the other hand, if a woman could access the resources or opportunities available through the UNHCR-sponsored WVV project-such as a transfer to one of the better coastal refugee camps, or even a chance at resettlement abroad through the Canadian or Australian 'Women-at-Risk' programs-she might maintain family approval. This kind of speculation led to a number of what were thought to be false claims of rape on the part of Somali women refugees (personal interview, UNHCR junior staff member, Geneva, 25 October 1994).

In order to prosecute, incidents of rape in Kenya must be reported to police within 24 hours of their occurrence. A medical certificate, based on a physical examination conducted by a physician to verify clinically that rape occurred, is also required. These legal and medical procedures at once legitimize and invariably publicize acts of rape. They seek to institutionalize women's assaulted bodies at a number of levels. Legal testimony, medical examinations, and the provision of therapy for 'women victims of violence' are all constitutive of power relations which tend to create institutionalized subjects. Whereas the rule of law and the enforcement of human rights are usually the articulated reasons for projects such as WVV, the microphysics of power that manage the politics of the body occur on a more local scale. The legal, medical, and therapeutic practices which name, authorize, and organize the treatment of sexual violence are the transfer points of power in the camps. 
The stigma of rape for a woman within Somali culture is severe. A system of blood money-or diya-is often invoked when accepted codes of behavior among Somalis are violated, as in the case of rape. The family of a woman who is raped, for example, might seek compensation from the family of the culprit in the form of cash or other assets, such as livestock. Although such agreements are often negotiated in the Dadaab camps, all efforts are made by UNHCR staff and Kenyan legal counsel provided by the Federacion Internacional De Abogadas (FIDA, International Federation of Women Lawyers) to utilize official channels so that prosecution in court remains possible. Universal codes of human rights and national provisions in criminal law come face to face with Somali codes of justice. Depending on the extent to which women refugees and their families perceive that they can gain material benefits from the project as compensation for being raped, they may approach UNHCR and report the crime. Conflicts between the human rights/international law approach of UNHCR and the socially accepted, culturallyspecific laws of the Somali refugees in the camps continues to be a problem for the WVV Project.

While the lawyers and medical staff working in the camps have the authority to define rape in official terms, Somali refugees often circumvent these legal and institutional circuits of power and invoke their own system of justice, including material exchange. Nancy Fraser's (1989) analysis of the 'politics of needs interpretation' suggests that contests among discourses occur at the 'site of the social'; proponents of the UN, Kenyan, legal, medical, and Somali discourses seek discursive hegemony. International and Kenyan law indicates public punishment for rape. Evidence suggests, however, that many of the Somalis affected would prefer to settle these matters out of public purview, through more discreet agreements of compensation, usually between the men in the families affected by the woman's rape (personal interview with lawyer from FIDA, Dadaab, 22 November 1994). WVV staff publicize the laws against sexual violence and seek prosecution in cases of rape and related crimes.

Employing Nancy Fraser's (1989) approach, UNHCR and the WVV project work together with the legal and medical authorities in place as oppositional and expert discourses in a struggle for rights-based relations of power and justice. For Fraser, oppositional discourses force relations of power that have been sequestered in the realm of the private to become public and, in turn, more politicized. While Fraser does not purport to analyze power relations across cultures and nations outside 'the West', her poststructuralist approach can be transposed to a transnational scale. Her 'site of the social'- the public location for politics and contests among discourses - is also the site of a powerful lobby to 'reprivatize' notions of punishment and compensation back to the more private 'family' realm in this case. Expert discourses add weight to either side; in the context of UN-sponsored refugee camps, legal, medical, and other experts tend to back those who pay their salaries and whose dominant culture they share. Refugee, local, and UN cultural practices come together to vie for power and efficacy at the site of the refugee camp.

During my fieldwork in the camps, the aftermath of sexual violence posed other questions of discursive politics imbued with contested markings of gender and culture. Genital mutilation, or female circumcision-depending on the discourse one employsbecame the focus of complex cultural politics after a young refugee woman was raped in Dagahaley camp. While accompanying the WVV counselor during a follow-up visit, I met the girl who had been raped and her mother. Her mother would not allow the girl to stay in the hospital after the attack. A local UNHCR employee at the scene, a Somali herself, explained the situation: 'she has to be stitched up; the wound is healing. 
They will do it the traditional way; it is more dangerous.' The act of rape tore the flesh sewn together during circumcision/genital mutilation. Her family and community discouraged her from becoming involved with UNHCR and other agencies unless she could get some personal, material benefit. Accordingly, the genital wound was to be treated by a woman trained in circumcision, rather than an MSF doctor. While MSF flatly opposes the practice of genital mutilation - as does UNHCR - its staff are usually prepared to perform the surgery required for women who are raped. Their rationale is that women who have been raped are less likely to risk infection if the recircumcision/ mutilation is performed in the hospital than in the community.

One's choice of words is intensely political: does one employ a discourse of cultural autonomy or of universal human rights? Is protest of practices of female genital mutilation, or circumcision, a morally coded cultural imperialism or a bid for justice? It is not surprising that much agreement on the issue across cultures in refugee camps is elusive. The tension between culture as universal and culture as particular is clear.

\section{Perfecting Practice: towards transnational practice}

We have to transform the field of social institutions into a vast experimental field, in such a way as to decide which taps need turning, which bolts need to be loosened here or there, to get the desired change; bearing in mind that a whole institutional complex, at present very fragile, will probably have to undergo a restructuring from top to bottom. (Michel Foucault cited in Young, 1993, p. 227)

Rather than simply criticize UNHCR's gender policies and the WVV Project as imperfect approaches to solving the problems of unequal power relations, I have analyzed some of their implications as responses predicated upon certain assumptions and constructed within a framework of 'UN humanism'. UN humanism and its approach to 'managing ethnic diversity' emphasize integration within a 'family of nations'. Yet it is precisely this notion of family that requires interrogation. Difference is acceptable in so far as it subscribes to the structures and relations of family. At a finer scale, violence against refugee women in and around the Dadaab camps has historical and political meanings which exceed the policies and practical efforts made to assist refugee women. This is not to condemn current efforts within UNHCR to recognize difference and 'do something', but to point out some of their limitations in humanitarian situations on the ground. Work to create conversations, strategies, and agreement among various parties at a cultural level, which is sensitive to other axes of difference including gender, is as important as the humanitarian functions that UNHCR fulfills.

UNHCR is an organization which responds to both the protection needs and practical needs of displaced people. It does so within an institutional and legal framework that situates the people it aims to assist in specific ways. Gender policy, then, is subject to the discipline of these schema and cannot wholly represent the range of possible responses that might be worked out in the field. Differences in culture and gender cannot simply be added to an overarching framework of humanitarian assistance, nor can the development of a single set of gender policies be applicable to all humanitarian situations. Spaces to negotiate both the meanings and modes of humanitarian intervention can be opened up, however, without losing sight of UNHCR's organizational goals. UNHCR can 'unframe' fixed notions of gender and cultural difference by taking such 'variables' much more seriously. 
At the outset of this article, I outlined some of the dangers of essentializing 'woman' as well as the risks associated with a liberal framework of multicultural UN humanism. By tracing some of the contradictions and assumptions of selected UNHCR gender policies, I have tried to expose the cultural assumptions of 'people-oriented planning', despite its good intentions and the reluctant climate in which it is disseminated. The integration and mainstreaming of gender as an agenda item of the humanitarian mandate is important. Specifying how gender and culture should be incorporated into refugee planning from what is an ahistorical and aspatial perspective is, however, less viable. I recall the quandary I faced as a field officer in Southern Somalia, charged with the responsibility of distributing agricultural tools and seed to people in a number of outlying villages decimated by civil war. The very idea that I could independently consult with the women concerned, as the POP framework would suggest, was culturally inappropriate for the context in which I found myself. The male elders were still the recognized leaders within the war-torn society, though their authority had been somewhat undermined by the instability of economic and political relations. They asked that I leave the goods with them for distribution, an idea not popular with the women who heard their request. The question then became, do I act as though I am part of the cultural context in which I find myself, that is, to give the seed, tools, and food to elders to allot at their discretion? Or do I act within my own culturally-defined perceptions of what is fair, in this case what I perceived to be the interests of the much larger number of disaffected women? In discussing this problem with Somalian UNHCR staff from the area, a number of observations shaped my decision: first, it is possible that Somali men have more than one wife and maintain more than one household; and second, women generally do most of the seeding and weeding in agricultural work. We decided to give every adult woman an equal portion of what was available, knowing that this plan would not be popular with the indigenous leadership. This scenario illustrates the negotiation and mutation of humanitarian practice on an ongoing basis.

The WVV Project fell prey to its own categories of clients, generating an intense cultural politics of its own. While UNHCR gender policy contradicted the manner in which the project was conceived and delivered, the international discourse of human rights politicized the violence against refugee women in North-east Kenya and the project went ahead. The WVV project is not the only UNHCR initiative which aims to identify vulnerable segments of the refugee population. It is standard practice in all areas of UNHGR competency to identify such groups and ensure adequate provision and protection (UNHCR, 1996). Again, the inclusion of vulnerable groups - which invariably refer to some women - as an item on the humanitarian agenda is important. Designating a priori what these groups are and how they should be incorporated into refugee planning is more problematic.

What might replace this additive model of integration in which gender difference and cultural diversity represent deviance from invisible but culturally dominant practices? Inderpal Grewal \& Caren Kaplan's (1994) work provides a partial answer, what they have called 'transnational feminist practices.' These practices are comprised of strategies that conceive of differences as linked, if unequal, and which upset commonplace markers of social, cultural, and political identity. Transnationalism has been broadly defined as an analytical perspective that focuses on the accelerating circulation of goods, people, money, information, ideas, culture, and I would add, politics (Shami, 1996). As a theoretical approach, transnationalism emerged out of postmodernist and Marxistinspired critiques of global capitalism and flexible accumulation. In one sense, transnational practices challenge a purely locational politics of global-local or center-periphery 
positioning in favor of messier links of historical and geographical contingency. They are strategies which engage and connect rather than distinguish and distance people of different locations-social, political, cultural, or otherwise. Such practices are at once materialist and discursive. They aim to blur the divide between discourse and practice, between people of 'the West and the rest', and to subvert reified categories such as 'Third World woman', 'Serb', 'Kurd', and 'other.' Between the universal subjects of UN humanism and essentialist concepts of 'refugee woman' are people of various, often unequal locations whose work is to connect with others, persuade others of their projects, and invoke positive change (Mohanty, 1991; Mouffe, 1992, 1995). Such deconstructive impulses have powerful political potential on one level, but their materialist impact is less convincing (Mitchell, 1997).

Within UNHCR, practical changes are necessary both in terms of emphasis and approach. In situations of humanitarian response, logistics, health and social services all depend upon cultural work-namely, negotiation, translation, and interpretation. To some extent this work is already being done, primarily by NGOs, and should be expanded by drawing on the geographically diverse and culturally attuned experience of NGO staff. At UNHCR, better practices might include ongoing discussions with refugees-women in particular-not simply of them, in an effort to bridge some of the social, cultural, and political difference and discursive distance which is reproduced and managed under the rubric of 'UN humanism'. This may seem too simple, and some agency staff would argue this is already being done. But as neoliberal thinking shifts political support from development budgets to more defined and finite humanitarian emergencies, there is also decreasing support for such 'non-essentials':

the long-established notion that refugees should be active participants in the management of their camps and assistance programmes is quietly being set aside. Increasingly, donor states assess humanitarian organizations in terms of their capacity to deliver emergency relief, rather than their ability to empower marginalized populations and to bring a degree of dignity to their lives. (UNHCR, 1997, p. 67)

UNHCR has seen extraordinary growth in its resources since the beginning of the 1990s. It can afford to do the job well, especially where it can draw upon the expertise of NGOs well-placed and experienced to assist. But are there staff positions whose primary function is to do the cultural work of communication, translation, and interpretation across all aspects of humanitarian assistance? Administration, protection, social services, and field staff' are all assumed to be gender-sensitive and culturally competent in the areas for which they are responsible, but there is not yet sufficient political prerogative or resource allocation to work through the gender and cultural implications of programming on a situation-by-situation basis. This needs to be made a priority. Effective assistance requires as much engagement with the cultural politics, geopolitics, and history of the place where people are disaffected as with the political and logistical challenges of finding and providing relief.

Women whose bodies, families, and communities bear the violent inscriptions of war and displacement are neither universal subjects, nor essentialized subjects in distinct locations. The conditions, locations, and responses to displacement are political: where openings exist, concrete links can be made across, within, and between categories and spatialized hierarchies of difference. The antagonism between culture as a universal and as cultural difference is long-standing. In the realm of refugee relief and humanitarian response, it cannot be resolved simply by introducing worldwide approaches, nor by 
treating categories of difference, such as gender and culture, in a fixed and isolated manner. Engaging gender, cultural, and other axes of difference in humanitarian emergencies demands operational guidelines that are subject to transformation when they meet the reality and the subjects of displacement. It requires taking differences more seriously and implementing - in the current situation-cultural workers who, alongside the water and sanitation experts, logistics personnel, protection officers, and health workers, negotiate, communicate, and collaborate with those affected.

\section{Acknowledgements}

The author would like to thank Wenona Giles, Gerry Pratt, Nadine Schuurman, and three anonymous reviewers for their comments on earlier drafts of this paper. Research for the paper was funded by the Social Sciences and Humanities Research Council of Canada, the International Development Research Centre (Ottawa), and York University's Centre for Refugee Studies (gender unit).

\section{NOTES}

[1] The word miscegenation first appeared in the Oxford English Dictionary in 1864, alluding to the polygenist position of distinct 'races' and the value of racial purity in contrast to 'mixed race' (Young, 1995).

[2] For a comprehensive review of UNHCR policy, Executive Committee conclusions, and legal protocols regarding women, see Refugee Survey Quarterly, 'Special Issue on Refugee Women', vol. 14, Summer 1995 published by UNHCR, Geneva.

[3] In 1993 the UN Relief and Rehabilitation Programme for Somalia outlined specific objectives as well as 'funding requests by sector' to finance the initiative. The sectors requiring funding noted in Table II of the document include, among others, civil administration, food security, logistics, potable water, education, health and nutrition, and Somali women. While it is true that the document was partly designed to appeal to potential funders, the separation of women from the other activities noted here also contradicts UNHGR's 'mainstreaming' policy.

[4] My own feminist politics focus on the unequal relations of power across relations of culture, sexuality, nationality, class, and other differences as well as gender, and emphasize the construction of subordinate categories and identities. They are also attentive to cultural location and material inequalities. The difference between my position and that of UNHCR is that UNHCR policy applies across cultures unproblematically. Cultural difference is subsumed within a single framework of emergency planning.

[5] The financing of the Women Victims of Violence Project raises other political questions. The initial estimated cost for WVV as a 3-month project, was US $\$ 1,119,401$, of which more than $50 \%$ was to be spent on improving the security of the camps. Police escorts during refugees' firewood collection, extensive fencing around residential sections of the camp to prevent bandit access, and assistance to Kenyan police by providing communication equipment and vehicle maintenance were among the measures proposed to achieve this goal (UNHCR, 1993d). The Canadian International Development Agency (CIDA), a major funder of the project, issued a mission report assessing the project's achievements late in 1994 (CIDA, 1994). Canada alone had contributed $\$ 3.25$ million, which represented $36 \%$ of project funds. While the project was assessed as having 'an important impact', the mission report observed that its funds were used to fill major gaps in general program budgets. The CIDA report noted that major project expenditures did not appear to be specific to women.

One of the main WVV budget items was the construction of 'live fencing'. Live thorn bushes are transplanted around the perimeter of camp compounds as a means of keeping bandits and potential assailants out. As of September 1994, 43 kilometres of fencing had been completed while another 54 kilometres remained to be constructed (UNHCR, 1994b). Economically, the WVV project has had a number of positive 'spin-off' effects for refugee labourers, contract construction workers, traders, and police officers. Some findings suggest that some WVV funds have been misdirected and used to pay for items which are not part of the project's mandate (CIDA, 1994). Based on the CIDA audit and its criticisms, the WVV Project sadly proved more useful for UN administrators and local police, for whom new vehicles were provided, than for the refugees affected by violence in the camps. 


\section{REFERENGES}

Abu-Lughod, LiLA (1991) Writing against culture, in: Richard G. Fox (Ed.) Recapturing Anthropology, pp. 137-162 (Sante Fe, NM, School for American Research).

Allan, Virginia R., Galey, Margaret E. \& Persinger, Mildred E. (1995) World Conference of International Women's Year, in: ANNe Winslow (Ed.) Women, Politics, and the United Nations, pp. 29-44 (Westport, GN, and London, Greenwood Press).

Anderson, Mary, Brazeau, Ann \& Overholt, Catherine (1992) A Framezork for People-oriented Planning in Refugee Situations Taking Account of Women, Men and Children: a practical planning tool for refugee workers (Geneva, UNHCR).

Barlow, Tani (1994) Theorizing woman: Funü, Guojia, fiating [Ghinese Women, Chinese State, Chinese Family] in: INDERPal GREwal \& GAREN KAPLAN (Eds) Scattered Hegemonies: postmodernity and transnational feminist practices, pp. 173-196 (Minneapolis, MN, University of Minnesota Press).

Canadian International Development Agency (1994) Mission Report on UNHGR Project WVV in Kenya, International Humanitarian Assistance Division, 28 August-5 September.

GockbURn, GYNTHIA (1996) Research on women in conflict zones: questions of method, paper presented at the Women in Conflict Zones Network Meeting, Toronto, 16 November.

Grosby, Alison, Giles, Wenona \& Korac, Maja (1996) Women in Conflict Zones Network, Discussion Paper No. 1, draft, York University, June.

de Lalretis, Teresa (1990) Eccentric subjects: feminist theory and historical consciousness, Feminist Studies, 16 , pp. $115-150$.

Escobar, ARTURo (1995) Encountering Development: the making and unmaking of the Third World (Princeton, NJ, Princeton University Press).

Fraser, Nancy (1989) Unruly Practices (Minneapolis, MN, University of Minnesota Press).

Galey, Margaret E. (1995) Women find a place, in: Anne Winslow (Ed.) Women, Politics, and the United Nations, pp. 11-27 (Westport, GN and London, Greenwood Press).

Gregory, Derek (1994) Humanistic geography, in: R. J. Johnston, Derek Gregory \& David M. SMith (Eds) The Dictionary of Human Geography, 3rd edn, pp. 263-266 (Oxford, Blackwell).

Grewal, INderpal (1994) Autobiographical subjects, diasporic locations, in: Inderpal Grewal \& Caren KAPLAN (Eds) Scattered Hegemonies: postmodernity and transnational feminist practices, pp. 231-254 (Minneapolis, MN, University of Minnesota Press).

Grewal, Inderpal \& Kaplan, Garen (1994) Introduction: transnational feminist practices and questions of postmodernity, in: INDERPal Grewal \& Caren Kaplan (Eds) Scattered Hegemonies: postmodernity and transnational feminist practices, pp. 1-33 (Minneapolis, MN, Minnesota University Press).

Haraway, Donna (1989) Primate Visions (New York and London, Routledge).

HirshmaN, Mitu (1995) Women and development: a critique, in: Marianne Marchand \& Jane Parpar'T (Eds) Feminism/Postmodernism/Development, pp. 42-55 (New York and London, Routledge).

HOOKS, BELL (1992) Representing Whiteness in the Black imagination, in: LAWRENGE GRossberG, Cary Nelson \& Paula A. Treighler (Eds) Cultural Studies, pp. 338-346 (New York and London, Routledge).

KaPLAN, Caren (1995) 'A world without boundaries': the Body Shop's trans/national geographics, Social Text, 43 , pp. $45-66$.

MALKKI, LIISA (1992) National geographic: the rooting of peoples and the territorialization of national identity among scholars and refugees, Cultural Anthropology, 7, pp. 24-43.

Marchand, Marianne \& Parpart, Jane (1995) Expolding the canon: an introduction/conclusion, in: Marianne Marchand \& Jane Parpart (Eds) Feminism/Postmodernism/Development, pp. 1-22 (New York and London, Routledge).

Mitchell, KathaRyn (1997) Different diasporas and the hype of hybridity, Environment and Planning D: Society and Space, 15, pp. 533-554.

Mohanty, Ghandra Talpade (1991) Under Western eyes, in: Chandra Talpade Mohanty, Ann Russo \& Lourdes TORRES (Eds) Third World Women and the Politics of Feminism (Bloomington and Indianapolis, IN, University of Indiana Press).

MOUfFe, Chantal (1992) Feminism, citizenship, and radical democratic politics, in: JudiTH BUTLER \& JOAN SCOTT (Eds) Feminists Theorize the Political, pp. 369-384 (New York and London: Routledge).

Mouffe, Ghantal (1995) Post-Marxism: democracy and identity, Environment and Planning D: Society and Space, 13, pp. 259-265.

Parpart, Jane (1995) Post-modernism, gender and development, in: Jonathan Crush (Ed.) Power of Development., pp. 253-265 (London and New York, Routledge). 
Pietila, HilkKa \& Vickers, JEANne (1996) Making Women Matter: the role of the United Nations (London and Atlantic Highland, NJ, Zed Books).

Pred, Alan \& Watts, Michael (1992) Reworking Modernity (New Brunswick, NJ, Rutgers University Press). SASSEN, SASKIA (1996) Losing control?: sovereignty in an age of globalization (New York, Columbia University Press).

Shami, Seteney (1996) Transnationalism and refugee studies: rethinking forced migration and identity in the Middle East, Journal of Refugee Studies, 9, pp. 3-26.

SHOHAT, ElLa \& STAM, ROBERT (1994) Unthinking Eurocentrism: multiculturalism and the media (New York and London, Routledge).

SMrth, Dorothy E. (1993) Texts, Facts, and Femininity: exploring the relations of ruling (New York and London, Routledge).

SPARKE, MATTHEW (forthcoming 1999) Negotiating Nation-States: North American geographies of culture and capitalism (Minneapolis, MN, University of Minnesota Press).

United Nations (1993) United Nations Relief and Rehabilitation Programme for Somalia--Covering the Period 1 March-31 December 1993, 11 March.

United Nations High Commissioner for Refugees (1990) UNHCR policy on refugee women, Geneva, August.

United Nations High Gommissioner for Refugees (1991) Guidelines on the protection of refugee women, Geneva, July.

United Nations High Commissioner for Refugees (1993a) The State of the World's Refugees: the challenge of protection (Toronto, Penguin).

United Nations High Commissioner for Refugees (1993b) Note on certain aspects of sexual violence against refugee women, Executive Committee, A/AC.96/822, 12 October.

United Nations High Commissioner for Refugees (1993c) Making the linkages: protection and assistance policy and programming to benefit refugee women, Joint Meeting of Sub-Committees of Administration and Financial Matters and of the Whole on International Protection. Document EC/1993/SC.2/crp. 16, May.

United Nations High Commissioner for Refugees (I993d) Refugee Women Victims of Violence: a special project by UNHCR, a proposal, Nairobi, October.

United Nations High Commissioner for Refugees (1994a) Country Operations Plan--Kenya, Nairobi, October.

United Nations High Commissioner for Refugees (1994b) Information Bulletin, 'Kenya, Southern Somalia', Nairobi, September.

United Nations High Commissioner for Refugees (1995) The State of the World's Refugees: in search of solutions (Oxford and New York, Oxford University Press).

UNITED NATIONS HIGH COMMISSIONER FOR REFUGEes (1996) Handbook Voluntary Repatriation: international protection (Geneva, UNHCR).

United Nations High COMmissioner FOR Refugees (1997) The State of the World's Refugees: a humanitarian agenda (Oxford and New York, Oxford University Press).

Winslow, Anne (1995) Specialized agencies and the World Bank, in: ANNE Winslow (Ed.) Women, Politics, and the United Nations, pp. 155-175 (Westport, CT and London, Greenwood Press).

YOUng, ROBERT (1995) Colonial Desire: hybridity in theory, culture and race (New York and London, Routledge). YOUNT, MARK (1993) The normalizing powers of affirmative action, in: JoHN GapUTO \& MARK YOUNT (Eds) Foucault and the Critique of Institutions, pp. 191-229 (University Park, PA, Pennsylvania State University). 